\title{
Preferential petroleum migration pathways and prediction of petroleum occurrence in sedimentary basins: A review
}

\author{
Hao Fang ${ }^{1 *}$, Zou Huayao ${ }^{1}$ and Gong Zaisheng ${ }^{2}$ \\ ${ }^{1}$ State Key Laboratory of Petroleum Resources and Prospecting, China University of Petroleum, Beijing 102249, China \\ ${ }^{2}$ China National Offshore Oil Corporation, Beijing 100027, China
}

(C) China University of Petroleum (Beijing) and Springer-Verlag Berlin Heidelberg 2010

\begin{abstract}
The aim of this paper is to review the major points of contention concerning secondary petroleum migration, to discuss the nature and primary controls of the positions of petroleum migration pathways in sedimentary basins, and to illustrate the importance of preferential petroleum migration pathways for the formation of large oil/gas fields away from generative kitchens. There is competition between the driving force (buoyancy) and the restraining force (capillary pressure controlled largely by permeability contrast) in controlling the positions of petroleum migration pathways in heterogeneous carrier beds. At a large scale, there is a critical angle of dip of the carrier beds which determines the relative importance of structural morphology or permeability contrasts in controlling the positions of petroleum migration pathways in heterogeneous carrier beds. Maximum-driving-force-controlled migration pathways occur in carrier beds with an angle of dip greater than the critical dip and the positions of petroleum migration pathways are controlled mainly by the morphology of the sealing surfaces. Minimum-restraining-force-determined migration pathways occur in carrier beds with an angle of dip smaller than the critical angle where permeability contrasts would exert a more important influence on the positions of petroleum migration pathways. Preferential petroleum migration pathways (PPMP), defined as very restricted portions of carrier-beds that focus or concentrate petroleum from a large area of the generative kitchen, determine the distribution of oil and gas in sedimentary basins. The focusing of petroleum originating from a large area of the generative kitchens into restricted channels seems to be essential not only for long-range petroleum migration in hydrostatic conditions, but also for the formation of large oil or gas fields. Regions may miss out on petroleum migration because of its three-dimensional behavior, and two-dimensional migration modeling may be misleading in predicting petroleum occurrences in certain circumstances.
\end{abstract}

Key words: Secondary petroleum migration, heterogeneous carrier beds, preferential petroleum migration pathways, petroleum occurrence

\section{Introduction}

The process of petroleum expulsion from source rocks into reservoirs or carrier beds is called primary migration, and the process of petroleum migration within the carrier beds is called secondary petroleum migration (Tissot and Welte, 1984; England et al, 1987; England, 1994; Hunt, 1996). The physical mechanics of oil and gas migration in carrier beds (secondary migration) have been well established (Schowalter, 1979; England et al, 1987; England, 1994). The driving forces for secondary petroleum migration are buoyancy and groundwater flow, and the restraining force

*Corresponding author. email: Haofang@cup.edu.cn Received December 8, 2009 is capillary pressure which increases with decreasing porethroat size, increasing interfacial tension and wettability. Petroleum migration pathways control the distribution of oil and gas in sedimentary basins (Demaison and Huizinga, 1991; Pratsch, 1994; Hindle, 1997; Bekele et al, 2002), and can be understood as invisible bridges between source rocks and traps (Hao et al, 2009a). Tracing secondary petroleum migration pathways has been confirmed very useful for optimizing petroleum exploration. In this paper, we review the major points of contention concerning secondary petroleum migration, discuss the nature and primary controls of the positions of petroleum migration pathways in sedimentary basins, and demonstrate the importance of preferential petroleum migration pathways for the formation of large oil/ gas fields. 


\section{Major disputes concerning secondary petroleum migration}

Although the physical mechanics of secondary petroleum migration have been well established (Schowalter, 1979; England et al, 1987; England, 1994), major disputes exist concerning the styles and pathways of petroleum migration and their major controls in sedimentary basins.

(1) The nature and primary controls of petroleum migration pathways. There are two distinct schools of thought on the nature and primary controls of petroleum migration pathways in sedimentary basins (Hao et al, 2009c). The "restraining-force school" considers migration as a sheetlike migrating petroleum front (Rhea et al, 1994), and believes that the positions of petroleum migration pathways are largely controlled by permeability heterogeneity of the carrier beds (e.g., Rhea et al, 1994; Bekele et al, 1999; 2002) and are therefore difficult to predict effectively because of complications in characterizing permeability heterogeneity related to the extent of fracture permeability and permeability alteration due to diagenesis (Bekele et al, 2002). In contrast, the "driving-force school" views petroleum migration pathways as very restricted rivers or streams (Gussow, 1954; 1968; Dembicki and Anderson, 1989; Hindle, 1989; Catalan et al, 1992; Thomas and Clouse, 1995; Hindle, 1997). This school believes that the positions of petroleum migration pathways in sedimentary basins are controlled largely by structural morphology (Gussow, 1968; Pratsch, 1983; Momper and Williams, 1984; Pratsch, 1986; 1988; 1994; Hindle, 1997; Welte et al, 2000), and that modeling of petroleum migration pathways can be a powerful tool to reduce exploration risk (Sylta, 1991; Hermans et al, 1992; Hindle, 1997; 1999).

(2) The role of groundwater flow for long-distance petroleum migration. Toth (1987) and Roberts (1993a; 1993b) believe that petroleum is dissolved in the water phase during transport and water flow is a primary control on the distribution of petroleum in a sedimentary basin. Although Bekele et al $(1999 ; 2002)$ believe that petroleum migrates in a separate hydrocarbon phase, they consider water flow to be an essential control on migration pathways and for long-range petroleum migration. Hindle (1997) believes that groundwater flow is of minor importance in most situations, and is important only if a basin is sub-aerially exposed.

\section{Major controls of migration pathways in heterogeneous carrier beds}

As discussed above, conflicting opinions exist about the nature and primary controls of petroleum migration pathways in sedimentary basins. These arise from conflicting evidence.

\subsection{Evidence supporting permeability-controlled migration pathways}

In the published literature, evidence supporting the opinion that the position of petroleum migration pathways in heterogeneous carrier beds is primarily controlled by permeability contrast include three aspects.

(1) Simulation experiments. In the past 20 years, a number of experiments have been conducted (e.g., Dembicki and Anderson, 1989; Catalan et al, 1992; Thomas and Clouse, 1995; Zeng and Jin, 2003). The results of these experiments have greatly improved our understanding of the processes of secondary petroleum migration and entrapment. Most experiments suggest that the positions of petroleum migration pathways in heterogeneous carrier beds are controlled primarily by the porosity and permeability contrasts or by wettability of the carrier beds. For example, the simulation experiments by Zeng and Jin (2003) show that oil migrates preferentially through sand layers with high porosity and permeability. The results of these experiments suggest that at a small scale, the positions of petroleum migration pathways in heterogeneous carrier beds are primarily controlled by permeability contrasts, which means that the restraining force plays a determining role.

(2) Variation in oil saturation. Variations in oil saturation within a single field appear to indicate that the positions of petroleum migration pathways in heterogeneous carriers are controlled by permeability contrasts at an oil accumulation scale. For example, in oil reservoirs in which re-migration of accumulated oil does not occur, oil saturation increases with increasing porosity and permeability. The positive correlation of oil saturation and permeability suggests that oil preferentially migrates through and accumulates in reservoir portions with relatively high porosity and permeability.

(3) Compositional heterogeneities within oil reservoirs. Compositional heterogeneities within an oil field also suggest that the positions of petroleum migration pathways in heterogeneous carriers are controlled by permeability contrasts at an oil accumulation scale. Leythaeuser and Rückheim (1989) observed in a small oil reservoir in Germany that oil in sandstones with high porosity displayed relatively low contents of nitrogen, sulfur and oxygen (NSO) containing compounds and relatively high thermal maturity reflected by relatively high triaromatic steroids/monoaromatic steroids ratios (Fig. 1), whereas oil in sandstones with low porosity had higher contents of NSO compounds and lower thermal maturity. As porosity of the reservoir sandstones increases, the contents of NSO compounds decrease. The compositional heterogeneities reflect oil accumulation history (e.g., England et al, 1987; 1991; Leythaeuser and Rückheim, 1989; England, 1990; 2007; Horstad et al, 1995; Horstad and Larter, 1997; Hao et al, 1998b; 2000; Peters and Fowler, 2002). It can be inferred that oil reaching the trap earlier that had relatively low maturity with relatively high contents of NSO compounds accumulated preferentially in reservoir portions with high porosity and permeability. As the maturity of the source rock increased, oil reaching the trap later had relatively high maturity with low concentrations of NSO compounds. Such oil migrated into reservoir portions with relatively high porosity that had already been occupied by oil with relatively low maturity, and expelled the formerly accumulated oil into nearby reservoir portions with relatively low porosity. The compositional heterogeneities within the small oil reservoir (Fig. 1) implied that at the reservoir scale, oil preferentially migrates through or accumulates in reservoir portions with relatively high porosity and permeability, which means that the positions of petroleum migration pathways 
in heterogeneous carrier beds are primarily controlled by permeability contrasts.
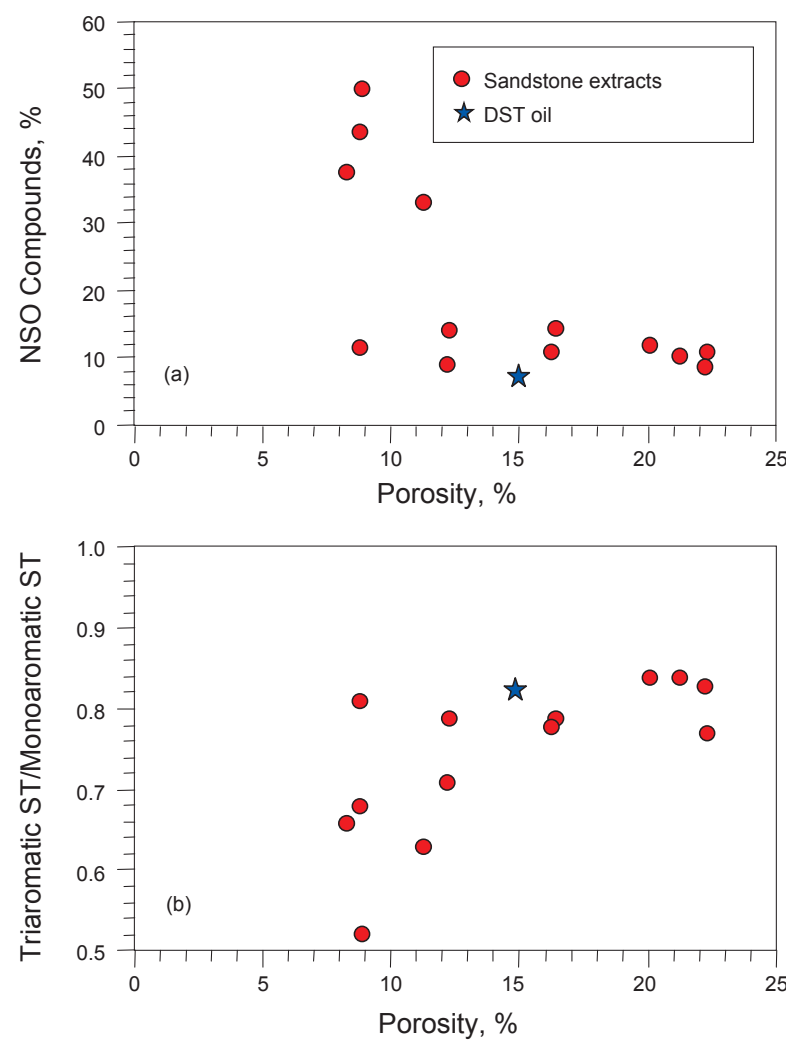

Fig. 1 Variation of the concentration of NSO compounds (a) and aromatic steroid parameter (b) with porosity for oil and sandstone extracts from an oilfield in Germany (data from Leythaeuser and Rückheim, 1989)

\subsection{Evidence supporting morphology-controlled migration pathways}

In recent years, several investigators have studied petroleum migration pathways and the distribution of oil and gas at a depression or sub-basin scale (e.g., Hindle, 1997; Bekele et al, 2002; Terken and Frewin, 2000; Terken et al, 2001; Luo et al, 2007; Hao et al, 2007; 2009c; Yu et al, 2009). These case studies provide evidence concerning the major controls of the petroleum migration pathways on a large scale.

Yu et al (2009) modeled secondary petroleum migration pathways in the Eastern Pearl River Mouth Basin (PRM Basin) using the PATHWAYS ${ }^{\text {TM }}$ model (Hindle, 1997), and calibrated the results of migration pathway modeling with all oil holes and dry wells. The PATHWAYS ${ }^{\mathrm{TM}}$ model is a simple, three-dimensional model which assumes that petroleum expelled from the source rocks migrates vertically until it encounters a sealing horizon, after which it moves in the direction of the most structurally elevated position below this sealing surface until it reaches the edge of the seal (Hindle, 1997). In other words, the PATHWAYS ${ }^{\mathrm{TM}}$ model assumes that the positions of petroleum migration pathways are controlled by the morphology of the sealing surface without taking into consideration of the influence of porosity and permeability heterogeneity of the carrier beds. In their modeling, areas where the Eocene Wenchang Formation had TOC contents greater than $2.0 \%$ and thermal maturity higher than $0.7 \% R_{\mathrm{o}}$ were defined as generative kitchens, sandstones in the Miocene Zhuhai and Zhujiang formations were set as migration conduits, and the bottom of the shaledominated Hanjiang Formation (shale content is up to $75 \%$ and the thickness of shales varies between 200 to $750 \mathrm{~m}$ ) directly overlying the Zhujiang Formation was set as the sealing surface. The modeling results (Fig. 2(a)) suggest that the asymmetric structural configuration of the Eastern PRM Basin leads to preferred petroleum migration to the southern and southeastern parts of the sub-basin. Yu et al (2009) used a parameter called migration predictive index (MPI) to assess the accuracy of the model prediction, and defined MPI as MPI $=$ [prediction of discoveries $(\%)+$ prediction of dry holes (\%)]/2. In the Eastern PRM Basin, the modeling results give an $\mathrm{MPI}_{1}$ (prediction of discoveries) of 97\% (37 drilled structural traps), and an $\mathrm{MPI}_{2}$ (prediction of dry holes) of $78.8 \%$ (18 drilled structural traps), with an overall MPI of $87.9 \%$ (Yu et al, 2009).

Hao et al (2007) conducted three-dimensional petroleum migration pathway modeling in the Bozhong sub-basin using the PATHWAYS ${ }^{\mathrm{TM}}$ model. In the modeling, areas where the Eocene Shahejie Formation or the third member of the Oligocene Dongying Formation had TOC contents greater than $2.0 \%$ and thermal maturity higher than $0.7 \%$ $R_{\mathrm{o}}$ were defined as generative kitchens, sandstones in the Guantao Formation were set as migration conduits, and the top of the Guantao Formation was set as the sealing surface. Faults inherited from the initial rift system cut through the source rocks and acted as vertical conduits bringing fluids expelled from the source rocks into the sandstones in the Guantao Formation (Gong, 1997; 2004; Hao, 2005). The modeling results (Fig. 2(b)) show that almost all commercial accumulations so far found in the Bozhong sub-basin have been successively predicted by the modeling. In terms of MPI, the modeling results give an $\mathrm{MPI}_{1}$ (prediction of discoveries) of $78 \%$, and an $\mathrm{MPI}_{2}$ (prediction of dry holes) of $100 \%$, with an overall MPI of $89 \%$. In addition, the predicted migration pathways have been supported by independent petroleum geochemical observations. For example, the modeling results predict three charging directions for the PL19-3 oilfield, the largest offshore oilfield in China. The PL19-3 field displayed considerable compositional heterogeneity, which suggested that the PL19-3 field was charged in the north by oil generated from the Dongying Formation in the eastern Bozhong Depression and Bodong Depression, in the southeast by oil generated from the Shahejie Formation in the Miaoxi Depression, and in the northwest by oil generated from the Shahejie Formation in the central Bozhong Depression (Hao et al, 2009b). Hao et al (2009c) carried out modeling of secondary migration pathways of both the high wax oil and the normal oil in the Damintun Depression using the PATHWAYS ${ }^{\mathrm{TM}}$ model (Fig. 2(c)). In the Damintun Depression, the modeling results give an $\mathrm{MPI}_{1}$ (prediction of discoveries) of $91.3 \%$, and an $\mathrm{MPI}_{2}$ (prediction of dry holes) of $90.4 \%$, with an overall MPI of $90.85 \%$ for the normal oil.

In all the three cases studied, the carrier beds show considerable heterogeneities, as suggested by the wide variation of measured porosities and permeabilities. However, the petroleum occurrences in all the three studied cases seem to have been effectively predicted (Fig. 2) by the 

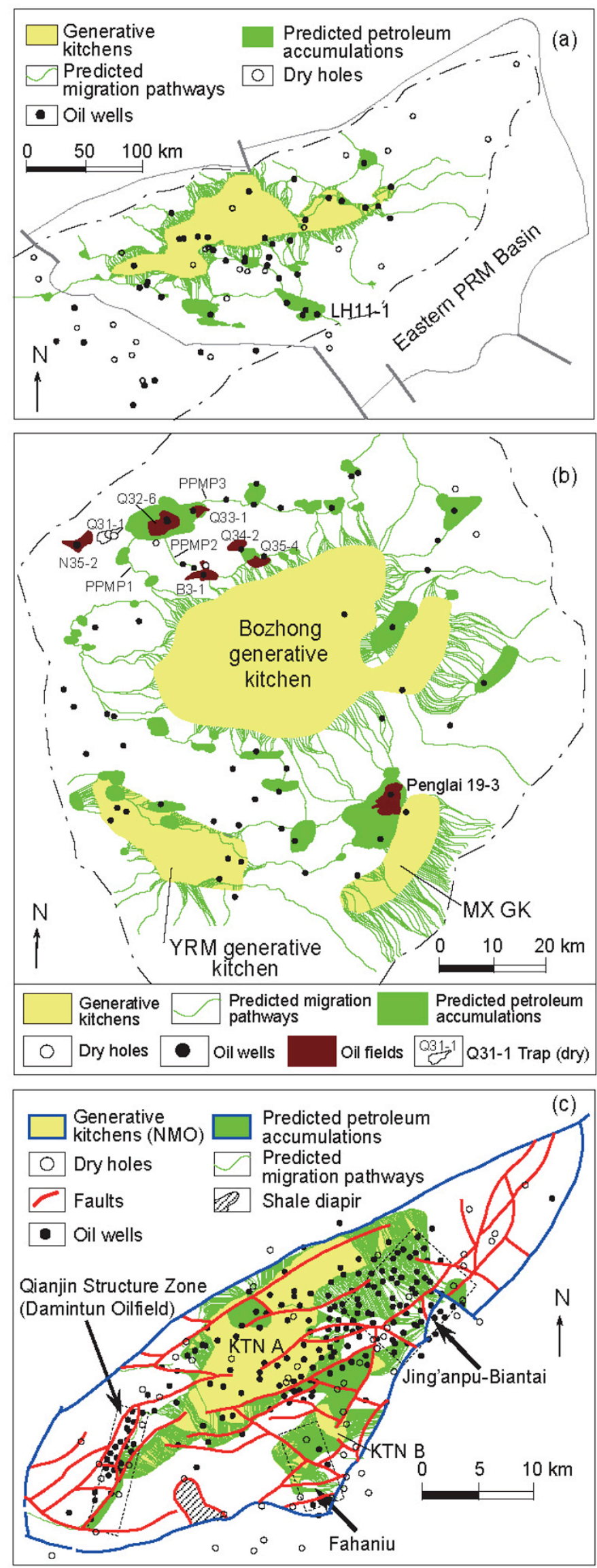

Fig. 2 Results of petroleum migration pathway modeling for the Eastern Pearl River Mouth Basin (a) (after Yu et al, 2009), the Bozhong Sub-basin (b) (modified from Hao et al, 2007), and the Damintun Depression (c) (after Hao et al, 2009c)
PATHWAYS $^{\text {TM }}$ model which assumes that the petroleum migration pathways are controlled by the structural morphology of the sealing surface without taking into consideration of the effect of carrier-bed heterogeneity. These case studies provide evidence that the positions of petroleum migration pathways in heterogeneous carrier beds at regional scale are controlled by morphology of the sealing surface.

\subsection{Primary controls of petroleum migration pathways in heterogeneous carrier beds: discussion}

The conflicting evidence discussed above indicate that the primary controls of the positions of petroleum migration pathways in heterogeneous carrier beds may be different at different scales and/or under different geological conditions.

According to the basic physical mechanics of secondary petroleum migration, in hydrostatic conditions, the driving force for secondary petroleum migration is the buoyancy, and the restraining force is the capillary pressure. Theoretically, petroleum in heterogeneous carrier beds will migrate in such a direction so that the difference between the driving force (buoyancy) and restraining force (capillary pressure) remains the maximum (Hao et al, 2007; 2009c). At the scale of centimeters to meters, the variation of buoyancy in different potential migration directions is small, but the variation of restraining force (capillary pressure) may be significant in heterogeneous carrier beds due to anisotropic permeabilities. As a result, the positions of petroleum migration pathways in heterogeneous carrier beds at the scale of centimeters to meters are determined primarily by permeability contrasts. Such situation could be called minimum-restrainingforce-determined migration pathways at small scale. This means that on a small scale (centimeters to meters) petroleum will preferentially migrate through (in petroleum migration pathways) or accumulate in (in trap reservoirs) the highpermeability portion of the rocks. This has been confirmed by both experiments (Zeng and Jin, 2003) and field based observations (Leythaeuser and Rückheim, 1989).

The situations at regional scale (from kilometers to subbasin or basin) are much more complicated. In cases where the variation of the buoyancy in different potential migration directions is more significant than permeability contrasts, the positions of petroleum migration pathways are largely controlled by the morphology of the sealing surface. We call such situation as maximum-driving-force-controlled migration pathways at large scale. In cases where the variation of the buoyancy in different potential migration directions is minor, the positions of petroleum migration pathways would be controlled primarily by the permeability contrasts. It seems that, theoretically, there is a critical angle of dip of the carrier beds which determines the relative importance of structural morphology or permeability contrasts in controlling the positions of petroleum migration pathways in heterogeneous carrier beds. In carrier beds with the angle of dip greater than the critical angle of dip and with complicated structural morphology, the variation of buoyancy in different potential migration directions is much more significant. As a result, the influence of permeability contrasts is minor, and the positions of petroleum migration pathways are controlled 
mainly by the complex morphology of the sealing surfaces (top surfaces of the carrier beds). In the lacustrine fault basins in China, the sealing surfaces (the bases of the regional cap rocks or the tops of the major carrier beds) usually have irregular, complex morphology usually with relatively large angle of dip because of intensive faulting, the existence of uplifts in the syn-rifting evolution stage, and the variation in subsidence/sedimentation rates in both syn-rifting and postrifting stages. This is perhaps one of the major reasons why the simple, morphology-controlled migration pathway model has predicted the petroleum occurrences in the lacustrine fault basins in China more accurately than it has in the Paris Basin (Hindle, 1997). By contrast, in carrier beds with angle of dip smaller than the critical angle of dip and with simple, regular structural morphology, the variation of the buoyancy in different potential migration directions is relatively small compared with carrier beds with complicated morphology and high angle of dip, and the permeability contrasts would exert a more important influence on the positions of petroleum migration pathways. This is perhaps the most important reason why petroleum migration pathways, and therefore the occurrences of most petroleum accumulations in the Ordos Basin could not be predicted without taking into consideration of the permeability variation (Luo et al, 2007).

\section{Preferential petroleum migration pathways (PPMP) and mechanisms for the formation of large oil/gas fields away from source kitchens}

In many basins, the largest oil fields are not within the generative kitchens, but are found in traps away from the generative kitchens. For instance, the LH11-1 oilfield, the largest oilfield so far found in the Pearl River Mouth Basin (oil reserve $2.4 \times 10^{8}$ ton), is 80 to $100 \mathrm{~km}$ away from the hydrocarbon generation area (Fig. 2(a)), and is among the oilfields that have the longest petroleum migration distances in sedimentary basins in China. The PL19-3 oilfield, the largest oilfield so far found in the Bohai Basin, is about 30 $\mathrm{km}$ away from the Bozhong generative kitchen (Fig. 2(b)). Therefore, it is of great significance for petroleum exploration to understand the mechanisms for the formation of large oil/ gas fields away from generative kitchens.

All case studies (Fig. 2) show that close to the generative kitchens, there are numerous "small petroleum streams", which seems to suggest that the so-called sheet-like migration may occur in carrier beds close to the generative kitchens. Away from the generative kitchens, these "small petroleum streams" focus into discrete "petroleum mainstreams". Hao et al (2007) call these "petroleum mainstreams" preferential petroleum migration pathways (PPMP) and define a PPMP as very restricted carrier-bed portion that focuses or concentrates petroleum from a large area of generative kitchen and is formed by focusing of numerous "small petroleum streams". As shown in Fig. 2, almost all commercial oil fields are on the predicted preferential petroleum migration pathways (PPMP), suggesting that PPMP controls petroleum distribution in sedimentary basins. What is more important is that, almost all large oilfields (oil reserves greater than $1 \times 10^{8}$ ton) are at the merging points of several preferential petroleum migration pathways and therefore have more than one preferential migration pathway to convey petroleum to the traps. Each preferential petroleum migration pathway is the result of the focusing of numerous "small petroleum streams". The merging of different preferential petroleum migration pathways focuses petroleum originating from a large area of the generative kitchens into one trap. This indicates that focusing of petroleum generated from a large area of kitchen is a prerequisite for the formation of large oil/gas fields away from source kitchens.

Petroleum that accumulated in traps away from generative kitchens must have experienced relatively long-distance lateral migration. The role of groundwater flow in longrange petroleum migration is one of the principal points of contention in petroleum migration. Garven (1989) believed that groundwater flow was a key to the formation of the giant oil sands deposits of the Western Canada Sedimentary Basin, and Bekele et al (2002) stated that oil could not have experienced long-range migration to form the distant oil fields in the Viking Formation in the Alberta Basin. In the Eastern PRM Basin, oil originating from the southern limit of the generative kitchen must have migrated more than $80 \mathrm{~km}$ to fill the LH11-1 field (Yu et al, 2009, Fig. 2(a)), and oil originating from the kitchen center must have migrated a much longer distance. The filling of the LH11-1 field (oil reserve of about $2.4 \times 10^{8}$ ton) and the predicted migration pathways suggest that petroleum could migrate over a long distance in hydrostatic conditions (without hydrodynamics) to form a large oilfield. It is noticeable that in the Eastern PRM Basin, oil originating from a large portion of the generative kitchen focuses through "small streams" into discrete "mainstreams" or preferential petroleum migration pathways (PPMP), and these discrete "petroleum mainstreams" merge further to form "channels" to convey oil into the LH11-1 structure (Yu et al, 2009, Fig. 2(a)). The focusing of oil originating from a large area of the generative kitchen, and the migration of oil through very restricted channels will ensure the petroleum filaments high enough to have efficient buoyancy to overcome capillary pressure to experience long-range migration in hydrostatic conditions (without the driving force of groundwater flow). It appears, therefore, that the existence of laterally-connective carrier beds, the concentration of petroleum originating from a large area of the generative kitchens, and the focusing of migrating petroleum into very restricted channels are the basic mechanisms for the formation of large distant oil/gas fields.

\section{Three-dimensional behaviors of petroleum migration and locating of petroleum accumulations}

The complexity of the sealing surface morphology, and the primary control of sealing surface morphology on the positions of migration pathways determine the threedimensional behavior of secondary petroleum migration. Two-dimensional petroleum migration modeling may provide misleading indications of potential petroleum accumulations in certain circumstances. Hao et al (2009a) conducted 
both two-dimensional and three-dimensional migration modeling on a hypothetical case, where the active source rock is overlain by widespread sandstone which is in return overlain by thick, widespread shale (Fig. 3(a) and 3(b)). Twodimensional modeling on section $\mathrm{S}-\mathrm{S}$ ' predicts that petroleum expelled from the generative kitchen migrates laterally and accumulates first in trap $T_{1}$, then spills from trap $T_{1}$ and migrates into trap $\mathrm{T}_{2}$ and then trap $\mathrm{T}_{3}$ (Fig. 3(b)). However, three-dimensional migration pathway modeling using the PATHWAYS $^{\text {TM }}$ model shows that petroleum originating from the generative kitchen instead focuses gradually into traps $\mathrm{T}_{4}$ and $\mathrm{T}_{5}$ (Fig. 3(b)). Only if the amount of generated hydrocarbon is high enough to fill trap $\mathrm{T}_{4}$ to the spill point,
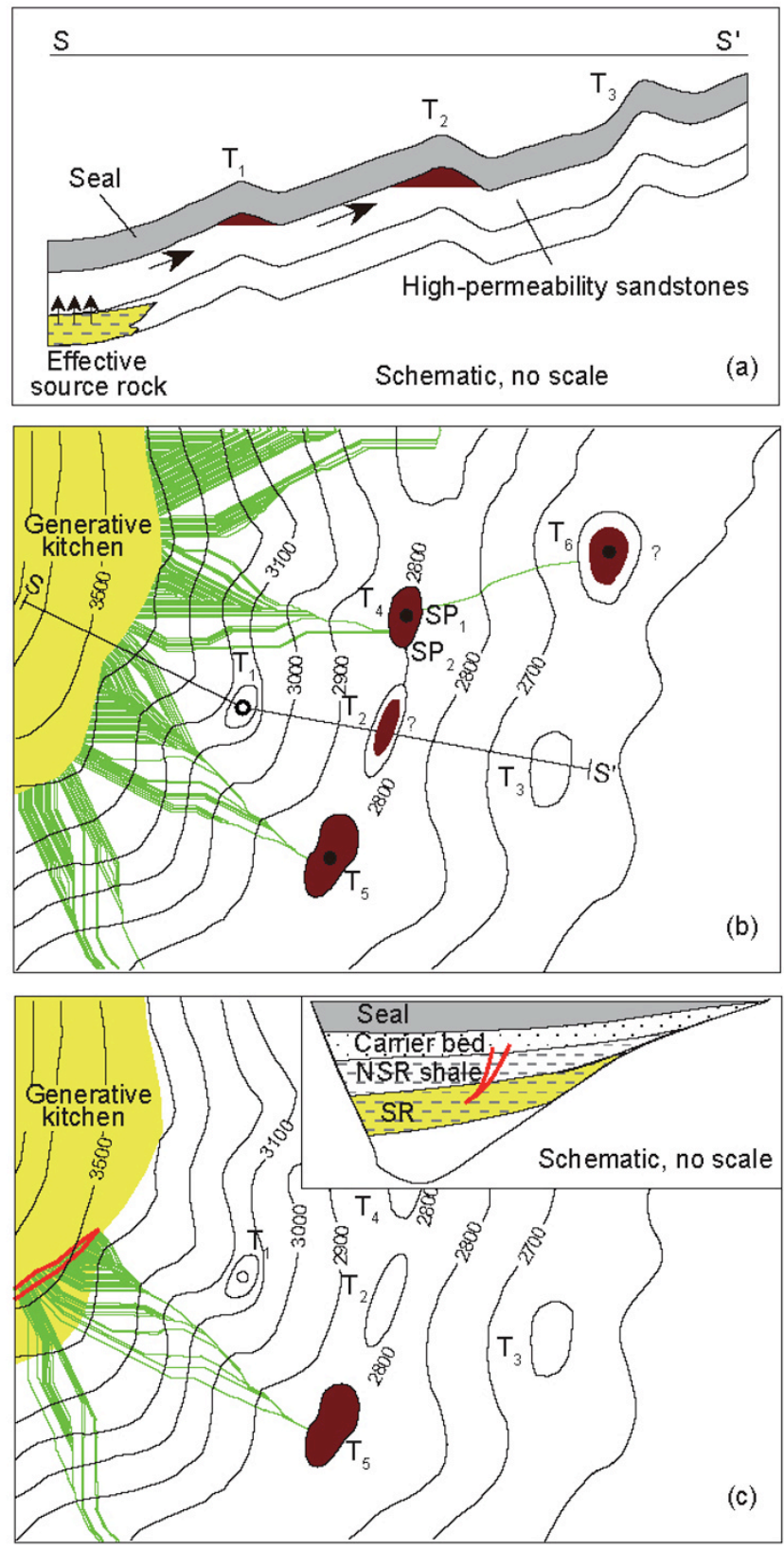

Fig. 3 Hypothetical case study showing the difference between twodimensional (a) and three-dimensional (b) modeling in predicting petroleum occurrences (modified from Hao et al, 2009a), and the petroleum migration pathways if only a fault is the effective "kitchen" for the carrier bed (c) SP: spill-point; SR: source rock; NSR shale: non-source rock shale and the spill point of trap $\mathrm{T}_{4}$ is at $\mathrm{SP}_{2}$, can trap $\mathrm{T}_{2}$ receive petroleum that spills from trap $\mathrm{T}_{4}$ (Fig. 3(b)). No matter how large the amount of hydrocarbons that the generative kitchen can provide is, trap $T_{1}$ cannot be filled because this trap is inaccessible to petroleum migration. This simple case indicates that although two-dimensional modeling is very useful in revealing the timing and processes of petroleum migration and accumulation in sedimentary basins, the predicted position of petroleum accumulations may be misleading, and three-dimensional modeling using simple model such as PATHWAYS ${ }^{\mathrm{TM}}$ model may be more useful in reducing exploration risk in lacustrine fault basins.

\section{Effective petroleum kitchens and petroleum migration pathways in lacustrine fault basins}

Although all three studied cases suggest that petroleum migration pathways in heterogeneous carrier beds can be modeled with a relatively high accuracy, there may be difficulties and uncertainties in predicting petroleum occurrences in other lacustrine fault basins. In addition to the possible changes in petroleum migration pathways caused by faults, facies changes in carrier beds and seal rock intervals (Hindle, 1997), the uncertainties come mainly from the difficulties in accurately determining the effective petroleum kitchens, which determine the starting-points of the petroleum migration pathways.

Determining the generative depression is very important for petroleum exploration (Demaison, 1984; Demaison and Huizinga, 1991; Magoon and Dow, 1994). The generative depressions or kitchens are usually assessed and defined based on the richness, types, and maturity of organic matter in the potential source rocks (Tissot and Welte, 1984; Hunt, 1996). The source potential index (SPI, a measure of the ultimate generative potential of a source rock measured in metric tons per square meter, Demaison and Huizinga, 1991) and oil transformation ratios (Hindle, 1997; 1999; Bekele et al, 1999) are quantitative parameters often used to define the generative kitchens. The expulsion efficiency of the source rocks is another factor affecting the effectiveness of the generative kitchens. Although many investigators believe that the expulsion efficiency is usually high (e.g., Miller, 1992), there are cases where the expulsion efficiency of source rocks has been confirmed to be relatively low (Riediger et al, 1990; Price and LeFever, 1994; Hao et al, 1998a). Even if the source rocks have high overall expulsion efficiencies, there are still uncertainties concerning the effective kitchens for a specific carrier bed used in migration pathway modeling. We define the part of the generative kitchen that has been expelling a considerable amount of hydrocarbons into a specific carrier bed as the effective generative kitchen (area) for this carrier bed. The centers of the lacustrine fault basins in China are usually more shale prone. It is common that in part of the generative kitchen area, there are thick shales between the source rock below and the carrier bed above. In such a case, the effective kitchen area for the carrier bed is much smaller than the generative kitchen area defined based 
on source rock geochemical parameters, and the modeled petroleum migration pathways will be considerably changed. In extreme case, the source rocks in the entire kitchen area are overlain by thick shales, and faults that cut through the source rocks (especially the graben-boundary faults) become the only conduits for petroleum charging into the carrier bed (inset in Fig. 3(c)). In such a case, the effective "kitchen" for the carrier bed is the faults, and the modeled petroleum migration pathways will be greatly changed (Fig. 3(c)). For the sake of predicting petroleum occurrences and reducing exploration risks, it is necessary to define accurately the preferential expulsion directions of the source rocks (so as to correctly select the carrier bed, Mackenzie and Quigley, 1988) and the effective kitchen for the selected carrier bed after the generative kitchens have been defined by detailed source rock geochemical studies.

\section{Conclusions}

The primary control of the position of petroleum migration pathways in heterogeneous carrier beds and the role of groundwater flow are the main points of contention for secondary petroleum migration. Evidence from both simulation experiments and geological observation indicate that the position of petroleum migration pathways in heterogeneous carrier beds could be primarily controlled either by permeability contrast (the minimum-restraining-forcedetermined migration pathways) or by structural morphology (the maximum-driving-force-controlled migration pathways), depending on the geological configuration especially the angle of dip of the carrier beds. Although groundwater flow may be essential for secondary petroleum migration in basins with intensive water recharge, petroleum can migrate over a long distance to form a large oilfield without driving force from groundwater flow where there are laterally-connective carrier beds and petroleum originating from a large area of the generative kitchens focuses into very restricted channels.

Preferential petroleum migration pathways are invisible bridges between source rocks and traps and directly control petroleum occurrences in sedimentary basins. Secondary petroleum migration is a three-dimensional behavior, and two-dimensional migration modeling may be misleading in predicting petroleum occurrences. Effectively characterizing the conduit systems and defining the "effective kitchen" for a specific carrier bed are essential for predicting petroleum distribution by three-dimensional migration modeling.

\section{Acknowledgements}

This study was supported by the National Natural Science Foundation of China (grant No. 90914006) and Program for Changjiang Scholars and Innovative Research Team in the University (IRT0658). We are appreciative of collaboration with and enthusiastic support from Qinglong Xia, Jingfu Wu, Gongcheng Zhang, Shui Yu, Shike Zhou, and Yonghua Guo in the CNOOC Research Center, and Zhanwen Zhang, Xiaoguang Li, Zhenyan Chen, Keyuan Guo, Jinyou Li, and Jianqun Jiang in the Liaohe Research Institute of Petroleum Exploration and Exploitation. Special thanks are extended to
Geofocus LTD for kindly providing the Pathways 4.0 and 5.1 software package.

\section{References}

Bekele E B, Person M A and Marsily G D. Petroleum migration pathways and charge concentration: a three-dimensional model: discussion. AAPG Bulletin. 1999. 83(6): 1015-1019

Bekele E B, Person M A, Rostron B J, et al. Modeling secondary oil migration with core-scale data: Viking Formation, Alberta Basin. AAPG Bulletin. 2002. 86(1): 55-74

Catalan L, Fu X W, Chatzis I, et al. An experimental study of secondary oil migration. AAPG Bulletin. 1992. 76(5): 638-650

Demaison G. The generative basin concept. In: Demaison G and Murris R J, eds., Petroleum Geochemistry and Basin Evaluation. AAPG Memoir 35. 1984. 1-14

Demaison G and Huizinga B J. Genetic classification of petroleum systems. AAPG Bulletin. 1991. 75(10): 1626-1643

Dembicki H J and Anderson M J. Secondary migration of oil: experiments supporting efficient movement of separate, buoyant oil phase along limited conduits. AAPG Bulletin. 1989. 73(8): 10181021

England W A. The organic geochemistry of petroleum reservoirs. Organic Geochemistry. 1990. 16(1-3): 415-425

England W A. Secondary migration and accumulation of hydrocarbons. In: Magoon L B and Dow W G, eds., The Petroleum System - From Source to Trap. AAPG Memoir 60. 1994. 211-217

England W A. Reservoir geochemistry-A reservoir engineering perspective. Journal of Petroleum Science and Engineering. 2007. 58(3-4): 344-354

England W A, Mackenzie A S, Mann D M, et al. The movement and entrapment of petroleum fluids in the subsurface. Journal of the Geological Society. 1987. 144(2): 327-347

England W A, Mann A L and Mann D M. Migration from source to trap. In: Merrill R K, ed., Source and Migration Processes and Evaluation Techniques. AAPG Treatise of Petroleum Geology. 1991. 23-46

Garven G. A hydrogeologic model for the formation of the giant oil sands deposits of the Western Canada sedimentary basin. American Journal of Science. 1989. 289: 105-166

Gong Z S. Giant Offshore Oil and Gas Fields in China. Beijing: Petroleum Industry Press. 1997 (in Chinese)

Gong Z S. Neotectonics and petroleum accumulation in offshore Chinese basins. Earth Science-Journal of China University of Geosciences. 2004. 25(2): 513-517 (in Chinese)

Gussow W C. Differential entrapment of oil and gas: a fundamental principle. AAPG Bulletin. 1954. 38: 816-853

Gussow W C. Migration of reservoir fluids. Journal of Petroleum Technology. 1968. 20(4): 353-363

Hao F. Kinetics of Hydrocarbon Generation and Mechanisms of Petroleum Accumulation in Overpressured Basins. Beijing: Science Press. 2005 (in Chinese)

Hao F, Li S T, Dong W L, et al. Abnormal organic matter maturation in the Yinggehai Basin, offshore South China Sea: Implications for hydrocarbon expulsion and fluid migration from overpressured systems. Journal of Petroleum Geology. 1998a. 21(4): 427-444

Hao F, Li S T, Gong Z S, et al. Thermal regime, inter-reservoir compositional heterogeneities, and reservoir-filling history of the Dongfang Gas Field, Yinggehai Basin, South China Sea: Evidence for episodic fluid injections in overpressured basins. AAPG Bulletin. 2000. 84: 607-626

Hao F, Li S T, Sun Y C, et al. Geology, compositional heterogeneities and geochemical origin of the Yacheng Gas Field, Qiongdongnan Basin, South China Sea. AAPG Bulletin. 1998b. 82(7): 1372-1384 
Hao F, Zhou X H, Zhu Y M, et al. Mechanisms for oil depletion and enrichment on the Shijiutuo Uplift, Bohai Bay Basin, China. AAPG Bulletin. 2009a. 93(8): 1015-1037

Hao F, Zhou X H, Zhu Y M, et al. Charging of the Neogene Penglai 19-3 field, Bohai Bay Basin, China: Oil accumulation in a young trap in an active fault zone. AAPG Bulletin. 2009b. 93(2): 155-179

Hao F, Zou H Y, Gong Z S, et al. Petroleum migration and accumulation in the Bozhong sub-basin, Bohai Bay Basin, China: Significance of preferential petroleum migration pathways (PPMP) for the formation of large oilfields in lacustrine fault basins. Marine and Petroleum Geology. 2007. 24(1): 1-13

Hao F, Zou H Y, Li X G, et al. Migration and occurrence of high wax oils in the Damintun Depression, Northeast, China: Implication for primary controls of petroleum migration pathways in heterogeneous carrier beds. Journal of Petroleum Science and Engineering. 2009c. 67(3-4): 105-115

Hermans L, Van Kuyk A D, Lehner F K, et al. Modeling secondary hydrocarbon migration in Haltenbanken, Norway. In: Larsen R M, Brekke H, Larsen B T, et al, eds., Structural and Tectonic Modeling and Its Applications to Petroleum Geology. Norwegian Petroleum Society Special Publication 1. 1992. 305-323

Hindle A D. Downthrown traps of the NW Witch Ground Graben, UK North Sea. Journal of Petroleum Geology. 1989. 12: 405-418

Hindle A D. Petroleum migration pathways and charge concentration: a three-dimensional model. AAPG Bulletin. 1997. 81(9): 1451-1481

Hindle A D. Petroleum migration pathways and charge concentration: a three-dimensional model: reply. AAPG Bulletin. 1999. 83(6): 10201023

Horstad I and Larter S R. Petroleum migration, alteration and remigration within Troll Field, Norwegian North Sea. AAPG Bulletin. 1997. 81(2): 222-248

Horstad I, Larter S R and Mills N. Migration of hydrocarbons in the Tampen Spur area, Norwegian North Sea: a reservoir geochemical evaluation. In: Cubitt J M and England W A, eds., The Geochemistry of Reservoirs. Geological Society Special Publication No. 86. 1995. 159-183

Hunt J M. Petroleum Geology and Geochemistry (2nd Edition). San Francisco: WH Freeman and Company. 1996. 743p

Leythaeuser D and Rückheim J. Heterogeneity of oil composition within a reservoir as a reflection of accumulation history. Geochimica et Cosmochimica Acta. 1989. 53(8): 2119-2123

Luo X R, Yu J, Zhang L P, et al. Numerical modeling of secondary migration and its applications to Chang-6 Member of Yanchang Formation (Upper Triassic), Longdong area, Ordos Basin. Science in China, Series D: Earth Sciences. 2007. 50(Supp. 2): 91-102

Mackenzie A S and Quigley T M. Principles of geochemical prospect appraisal. AAPG Bulletin. 1988. 72(4): 399-415

Magoon L B and Dow W G. The petroleum system. In: Magoon L B and Dow W G, eds., The Petroleum System - from Source to Trap. AAPG Memoir 60. 1994. 3-24

Miller R G. The global oil system: the relationship between oil generation, loss, half-life, and the world crude oil resource. AAPG Bulletin. 1992. 76(4): 489-500

Momper J A and Williams J A. Geochemical exploration in the Powder River Basin. In: Demaison G D and Murris R J, eds., Petroleum Geochemistry and Basin Evaluation. AAPG Memoir 35. 1984 181-191

Peters K E and Fowler M G. Applications of petroleum geochemistry to exploration and reservoir management. Organic Geochemistry. 2002.
33(1): 5-36

Pratsch J C. Gasfields, NW German Basin: secondary gas migration as a major geologic parameter. Journal of Petroleum Geology. 1983. 5(3): 229-244

Pratsch J C. The distribution of major oil and gas reserves in regional basin structures-an example from the Powder River Basin, Wyoming, USA. Journal of Petroleum Geology. 1986. 9(4): 393-412

Pratsch J C. Focused gas migration and concentration of deep gas accumulations, NW German Basin. In: Beaumont E A and Foster N H, eds., Geochemistry. AAPG Treatise of Petroleum Geology. 1988. 8: 613-619

Pratsch J C. The location of major oil and gas fields: examples from the Andean foreland. Journal of Petroleum Geology. 1994. 17(3): 327338

Price L C and LeFever J. Dysfunctionalism in the Williston Basin: the Bakken/mid-Madison petroleum system. Bulletin of Canadian Petroleum Geology. 1994. 42(2): 187-218

Rhea L, Person M, Marsily G D, et al. Geostatistical models of secondary oil migration within heterogeneous carrier beds: a theoretical example. AAPG Bulletin. 1994. 78(11): 1679-1691

Riediger L C, Fowler M G, Snowdon L R, et al. Source rock analysis of the Lower Jurassic "Nordeg Member" and oil-source rock correlations, NW Alberta and NE British Columbia. Bulletin of Canadian Petroleum Geology. 1990. 38A: 236-249

Roberts W H. Deep water discharge: key to hydrocarbon and mineral deposits, part 1. Bulletin of the Houston Geological Society. 1993a. 36: $28-39$

Roberts W H. Deep water discharge: key to hydrocarbon and mineral deposits, part 2. Bulletin of the Houston Geological Society. 1993b. 36: $24-53$

Schowalter T T. Mechanics of secondary hydrocarbon migration and entrapment. AAPG Bulletin. 1979. 63(5): 723-760

Sylta $\varnothing$. Modeling of secondary migration and entrapment of a multicomponent hydrocarbon mixture using equation of state and raytracing modeling techniques. In: England W A and Fleet A J, eds., Petroleum Migration. Geological Society Special Publication 59. 1991. 111-122

Terken J M J and Frewin N L. The Dhahaban petroleum system of Oman. AAPG Bulletin. 2000. 84(4): 523-544

Terken J M J, Frewin N L and Indrelid S L. Petroleum systems of Oman: Charge timing and risks. AAPG Bulletin. 2001. 85(10): 1817-1845

Thomas M M and Clouse J A. Scaled physical model of secondary oil migration. AAPG Bulletin. 1995. 79(1): 19-29

Tissot B P and Welte D H. Petroleum Formation and Occurrence (2nd Edition). Berlin: Springer-Verlag. 1984. 699p

Toth J. Petroleum hydrogeology: a new basic in exploration. World Oil. 1987. 205(3): 48-50

Welte D H, Hantschel T, Wygrala B P, et al. Aspects of petroleum migration modelling (In: Proceedings of Geofluids III, Third international conference on fluid evolution, migration and interaction in sedimentary basins and orogenic belts). Journal of Geochemical Exploration. 2000. 69-70: 711-714

Yu J N, Zou H Y and Gong Z S. Preferential petroleum migration pathways in eastern Pearl River Mouth Basin, Offshore South China Sea. Journal of Earth Science. 2009. 20(4): 720-730

Zeng $\mathrm{J} \mathrm{H}$ and Jin Z J. Experimental investigation of episodic oil migration along fault systems. Journal of Geochemical Exploration. 2003. 78-79: 493-498

(Edited by Hao Jie) 